\title{
Hubungan Partisipasi Umat Kristen Dalam Dunia Politik Dan Pendidikan Terhadap Mandat Amanat Agung
}

\author{
Ronald Sianipar, ${ }^{1}$ Mangiring Tua Togatorop, ${ }^{2}$ Rupus ${ }^{3}$ \\ Prodi Studi Teologi, STT Real Batam \\ Prodi Studi Teologi, STT Real Batam \\ Prodi Studi Teologi, STT Real Batam \\ sianiparamos@gmail.com
}

\begin{abstract}
The church is the representative of the kingdom of God on earth and is commanded to bring the gospel message to all people on earth. A missionary church is a church that carries out missions. The word "mission" or "mission (English)" comes from the Latin word "missio" which is taken from the word "mittere", is a translation of the Greek word "apostello", which means "to send" or "send". In general the word mission can refer to the sending of someone with a specific purpose, for example an art mission, a cultural mission. The terms "mission" and "missions" are not the same. Missiologists distinguish between the two terms. "Mission" is a whole that God studies the church, whether it is in the service of God, church members, or people who do not believe in Christ. While "missions" are the church's participation in the research of the Gospel preaching that God entrusted to His church. therefore the mandate of the Great Commission must be the main concern of Christians. with the mandate of the Great Commission, the Church can assess and feel a significant Church growth. For example: the more the growth of Church people in terms of quantity, the more planting of the Church, the more affordable the unreached, the more the life of the missionary soul in the Church. prihal is very much determined by the life of the Church in mission, so that the call to mission is something that is expected by a Church.

Keywords: Participation, Christian, Politics, Education,Great Commission
\end{abstract}

\begin{abstract}
Abstrak
Gereja adalah wakil dari Kerajaan Allah di dunia ini dan diperintahkan untuk membawa berita Injil ke semua manusia di bumi. Sebuah gereja yang misioner adalah gereja yang melaksanakan misi. Kata "misi" atau "mission (Inggris)" berasal dari kata Latin "missio" yang diangkat dari kata "mittere", merupakan terjemahan dari kata Yunani "apostello", yang artinya "mengirim" atau "mengutus". Secara umum kata misi bisa merujuk pada pengutusan seseorang dengan tujuan khusus, misalnya misi kesenian, misi budaya. Istilah "mission" dan "missions" tidaklah sama. Para ahli misiologi membedakan kedua istilah tersebut. "Mission" merupakan suatu keseluruhan yang Allah penelitiankan kepada gereja, baik itu bersifat pelayanan kepada Allah, anggota gereja, maupun orang yang belum percaya kepada Kristus. Sedangkan "missions" merupakan partisipasi gereja dalam penelitian peberitaan Injil yang Allah percayakan pada gereja-Nya. oleh karena itu mandat Amanat Agung ini harus menjadi perhatian utama umat Kristes. dengan mandat Amanat Agung ini, maka Gereja bisa menilai dan merasakan suatu pertumbuhan Gereja yang signifikan. Misalnya: semakin bertumbuhnya Umat Gereja dalam hal kwantitas, semakin banyaknya penanaman Gereja, semakin terjangkau yang belum terjangkau, semakin hidupnya jiwa Misionaris didalam Gereja. prihal tersebut sangat ditentukan dengan kehidupan Gereja dalam bermisi, Sehingga panggilan bermisi sesuatu yang sangat diharapkan oleh suatu Gereja.

Kata kunci: Partisipasi, Kristen, Politik, Pendidikan, Amanat Agung
\end{abstract}




\section{PENDAHULUAN}

Amanat Agung itu demikian pentingnya, bukan saja karena merupakan misi utama semua gereja, tetapi juga karena gereja-gereja baru akan terbentuk apabila ada orang-orang yang taat terhadap mandat Amanat Agung tersebut. Tanpa Amanat Agung tidak akan ada gereja-gereja lokal. Mandat Amanat Agung menghasilkan gereja-gereja lokal.

Gereja adalah wakil dari Kerajaan Allah di dunia ini dan diperintahkan untuk membawa berita Injil ke semua manusia di bumi. Dalam tulisannya Fredy Simanjuntak menjelaskan fungsi Gereja berdampak keluar secara kualitas sebagai perkembangan tubuh yang progresif untuk menjadi seperti kepala, Yesus Kristus. Pertumbuhan ini dicerminkan sebagai dampak yang melingkupi gereja dan masyarakat sementara orang-orang percaya melihat apa yang Allah sedang lakukan. ${ }^{1}$ Jika kita melihat prioritas dari program-program, berbagai aktivitas sebuah gereja sekarang ini, kita mungkin bertanya-tanya apakah kita telah lupa atau bingung akan misi kita sebagai orang-orang percaya. Kita sibuk, tetapi sibuk mengerjakan apa? Berapa banyak program, pertemuan, dan aktivitas kita yang benar-benar menghasilkan jiwa-jiwa baru? Jika kita tergugah untuk memenuhi mandat Amanat Agung Kristus, maka kita harus menjadi gereja yang misioner. Hal ini tepat seperti yang dikatakan oleh Fransiskus Irwan Widjaja, bahwa Allah memanggil orang-orang pilihan-Nya untuk mengemban suatu mandat, dan untuk menjadi mitra kerja-Nya di dunia ini dalam programNya yang indah itu. ${ }^{2}$

Sebuah gereja yang misioner adalah gereja yang melaksanakan misi. Kata "misi" atau "mission (Inggris)" berasal dari kata Latin "missio" yang diangkat dari kata "mittere", merupakan terjemahan dari kata Yunani "apostello", yang artinya "mengirim" atau "mengutus". Secara umum kata misi bisa merujuk pada pengutusan seseorang dengan tujuan khusus, misalnya misi kesenian, misi budaya, dan lain-lain." Dalam konteks kekristenan, misi dipahami dalam arti pengiriman atau pengutusan gereja ke dalam dunia, khususnya melalui sekelompok pekerja yang disebut misionaris untuk menjangkau orangorang kepada Kristus sebagai Tuhan dan Juru Selamat. Dalam perkembangannya, pengertian misi pada saat ini mencakup makna yang cukup luas, yaitu: (1) Pengiriman atau pengutusan misionari ke daerah tertentu; (2) Aktivitas yang dijalankan para misionari; (3) Wilayah geografis di mana para misonaris bekerja; (4) Lembaga yang mengutus para misionaris; (5) ladang misi atau lapangan misi yaitu dunia non Kristen; (6) Pusat pengutusan misionaris; dan (7) Rangkaian pelayanan yang secara khusus dimaksudkan untuk menyebarkan agama Kristen dan pendiri jemaat baru. ${ }^{4}$

\footnotetext{
${ }^{1}$ Fredy Simanjuntak, "Kecerdasan Emosi Pemimpin Sebagai Tolok Ukur Gereja Yang Sehat," Real Didache 2, no. 1 (2017): 29-53.

${ }^{2}$ Fransiskus Irwan Widjaja, "Peran Gereja Terhadap Kehidupan Politik Di Wilayah Kepulauan Riau," Real Didache 1, no. 2 (2016): 117-140.

${ }^{3}$ M Samuel T. Gunawan, "Melaksanakan Amanat Agung Kristus," Situs Artikel Kristen Indonesia, 2017, http://artikel.sabda.org.

${ }^{4}$ Ibid.
} 
Istilah "mission" dan "missions" tidaklah sama. Para ahli misiologi membedakan kedua istilah tersebut. "Mission" merupakan suatu keseluruhan yang Allah penelitiankan kepada gereja, baik itu bersifat pelayanan kepada Allah, anggota gereja, maupun orang yang belum percaya kepada Kristus. Sedangkan "missions" merupakan partisipasi gereja dalam penelitian peberitaan Injil yang Allah percayakan pada gereja-Nya. oleh karena itu mandat Amanat Agung ini harus menjadi perhatian utama umat Kristes. dengan mandat Amanat Agung ini, maka Gereja bisa menilai dan merasakan suatu pertumbuhan Gereja yang signifikan. Misalnya: semakin bertumbuhnya Umat Gereja dalam hal kwantitas, semakin banyaknya penanaman Gereja, semakin terjangkau yang belum terjangkau, semakin hidupnya jiwa Misionaris didalam Gereja. prihal tersebut sangat ditentukan dengan kehidupan Gereja dalam bermisi, Sehingga panggilan bermisi sesuatu yang sangat diharapkan oleh suatu Gereja.

Sebenarnya Gereja punya tanggung jawab penuh akan kesejahteraan kota dimana gereja itu berada, karena dalam kitab Yeremia 29:7 ditegaskan bahwa kesejahteraan kota itu adalah kesjahteraan kita ( Gereja ) juga. Oleh karena itu, umat Kristen secara menyeluruh harus turut mengambil bagian, baik secara langsung maupun secara tidak langsung di dalam dunia perpolitikan di Indonesia. Secara langsung, yaitu dengan terjun ke dalam politik praktis sebagai politisi, ialah bagi mereka yang benar-benar yakin dipanggil Allah untuk melayaniNya di bidang politik dan memiliki talenta yang cukup di bidang itu, dan menjadi peserta pemilih di dalam pelaksanaan pemilihan umum dengan terus meminta tuntunan Allah untuk menentukan pilihannya. Secara tidak langsung, yaitu sesuai dengan penelitian orang-orang percaya yang harus turut menyejahterakan kota di mana kita ada sebagai bagian di dalamnya, sebagaimana dikatakan dalam 'Usahakanlah kesejahteraan kota ke mana kamu Aku buang, dan berdoalah untuk kota itu kepada TUHAN, sebab kesejahteraannya adalah kesejahteraanmu( Yeremia 27:7). ${ }^{5}$

Gereja harus benar-benar telibat dalam menjaga lingkungan, gereja harus giat mensosialisakanya terhadap warga Gereja melalui khotbah dan seminar. Jika Gereja terlalu menutup diri maka kehadiran Gereja gagal didalam kota dimana Gereja itu berada. Dr.T.B. Simatupang, memngatakan merasa berhutang ke Tuhan dan kenegara, dengan kesempatan yang Tuhan beri hidup dan berbagai jabatan beliau merasa belum maksimal melakukan apa yang Tuhan mau dalam hidupnya berdasarkan surat Paulus ke jemaat di roma. (Rm 1:14 ) sejak itu saya makin menyadari bahwa tiap hari,tiap minggu, tiap bulan dan tiap tahun dalam mandat yang diperpanjang itu harus saya gunakan untuk membayar hutang saya, ujar pak sim. Tuhan menghendaki agar kita membayar hutang itu kepada sesama kita, khusus kepada saudara kita yang lapar, telanjang,sakit atau penjara. ${ }^{6}$ Gereja harus terlibat dalam memberikan ide-ide kepemerintah dan kemasyarakat, yaitu ide pembangunan dan rasa cinta bertanah air dan berbangsa. Tuhan Yesus dan Rasul-rasul pada Gereja perdana bertindak

\footnotetext{
${ }^{5}$ H.V Matondang, Percakapan Dengan Dr.T.B Simatupang (Jakarta: BPK Gunung Mulia, 1989).85

${ }^{6}$ Ibid.
} 
secara langsung menagani orang miskin. Menurut Yesus, kerajaan Allah diperuntukkan bagi mereka yang miskin dan yang tidak berdaya. ${ }^{7}$ sumber daya Manusia yang kurang terlatih sehingga banyak kebijakan yang merugikan masyarakat kepulauan Anambas secara umum. Pembangunan yang kurang memadai, yang tidak sesuai dengan kebutuhan masyarakat yang mendesak cenderung diprioritaskan. Sehingga permasalahan diatas menuntut kebijakan politik yang akurat dan tepat sasaran.

Adapun faktor-faktor yang membuat terlaksananya mandat Amanat Agung adalah antara lain: taraf pendidikan pengelola Daerah sebagai pembuat kebijakan atau keputusan, makin tingginya kesadaran berbangsa dan bertanah air serta luasnya wawasan dari para pengelola Daerah akan menghasilkan kebijakan dan keputusan politik yang membangun lebih baik. selain itu dibutuhkan juga keahlian dan pengalaman yang luas.

Faktor tingkat kesejahteraan dari masyarakat,mutu kesehatan yang baik, tingkat penghasilan/perekonomian dan motifasi yang benar para pencari kekuasaan /kedudukan juga dapat mempengaruhi terlaksananya mandat Amanat Agung. Dengan demikian apakah tingkat kesejahteraan masyarakat atau mutu kesehatan dan motifasi motifasi yang benar para pencari kekuasaan /kedudukan ada hubungan dengan mandat Amanat Agung di kabupaten kepulauan Anambas?

Taraf pendidikan masyarakat juga bisa menjadi salah faktor terlaksanaya kehidupan yang membangun, masyarakat yang makin tinggi pendidikannya akan semakin cerdas mengkritisi kebijakan-kebijakan yang tidak pro terhadap kepentingan masyarakat. dan akan hati-hati menggunakan haknya untuk memilih para wakil atau anggota dewan yang benar-benar berkualitas dan ter uji.

Posisi wilayah yang strategis sangat menuntut kebijakan politik yang tepat sehingga menguntungkan wilayah kabupaten kepulauan Anambas, akan mendatangkan investasi, divisa sektor parawisata, pertanian, industri dan lain-lain. oleh karena itu posisi wilayah yang strategis menjadi salah satu faktor dari terlaksananya kehidupan politik yang membangun dan mensejahterakan masyarakat.

Kehidupan warga Gereja atau terbukanya terhadap politik, merupakan faktor penting dalam mandat Amanat Agung. melalui kehidupan warga Gereja yang peduli terhadap pembangunan dan kelestarian lingkungan akan membawa pengaruh terhadap masyarakat umum secara luas. Sudah waktunya Gerja Tuhan yang berkembang seiring dengan perkembangan Daerah dan kebebasan berpolitik, ikut mengambil peran serta terhadap kemajuan disegala bidang khususnya bidang politik.

Politik adalah salah satu bidang pelayanan dalam kehidupan berbangsa dan bernegara, sama pentingnya dengan bidang-bidang kehidupan lainnya. Menurut Luther dalam politik, pejabat pemerintah dan politisi jiga adalah imam yang mesti mempergunakan kemampuannya di bidang politik bagi kepentingan manusia dan Tuhan

\footnotetext{
${ }^{7}$ E.G Singgih, Iman Dan Politik Dalam Era Reformasi ( Jakarta: PT BPK GUNUNG MULIA ) 2000 Hal 48 (Jakarta: BPK Gunung Mulia, 2000).48
} 
(istilah "imamat am orang percaya"). Prinsip Marthin Luther tentang pekerjaan menggaris bawahi bahwa setiap pekerjaan adalah mimbar Allah. Orang Kristen bisa menjadi serdadu tetapi bukan berperang untuk menyerang orang lain melainkan karena keadaan darurat atau terpaksa demi mempertahankan kepentingan orang lain. Setiap pekerjaan yang di embankan bagi tiap-tiap orang harus memiliki tujuan dan berusaha supaya bermanfaat bagi orang lain.

Jika setiap orang kristen memiliki integritas dan memiliki sistem yang baik maka keterlibatannya dalam mewujudnyatakan politik, suatu sistem pemerintahan yang bersih,transparan dan memihak keseluruhan lapisan masyarakat akan tercapai.orang-orang kristen yang sudah dan sedang berada dalam dunia politik atau pemerintahan saat ini belum semuanya mempresentasikan nilai-nilai kristiani, sehingga masih banyak dari mereka yang perlu belajar mengenai kebenaran melalui Alkitab, baik dalam diperjanjian lama,terutama tentang seluk beluk pemerintahan raja daud, kehidupan daniel; maupun di perjajian baru, baik melalui sikap-sikap Yesus terhadap pemerintahan saat itu maupun tulisantulisan,terutama tulisan Rasul Paulus.

\section{METODE}

Berdasarkan teori tersebut diatas, maka penelitian ini merupakan penelitian deskriptif kuantitatif, data yang diperoleh dari sampel populasi penelitian dianalisis sesuai dengan metode statistik yang digunakan kemudian diinterprestasikan.

\section{HASIL DAN PEMBAHASAN}

Pertama, terlaksanya Amanat Agung mengakibatkan perubahan kehidupan Gereja dalam hal bermisi lebih baik. Hal ini terlihat dari perubahan pola pikir dengan tidak terpokusnya pelayanan hanya kedalam Gereja tetapi juga keluar. Yaitu dengan terlibatnya kehidupan Gereja melalui partisipasi kehidupan politik, pendidkan. Kedua, keterbukaan pemimpin Gereja terhadap lingkungan sangat memberikan pengaruh positif terhadap kehidupan jemaat dan masyarakat dalam hal kebersamaan dan keterbukaaan satu dengan lain tanpa meligat perbedaan etnis. Ketiga, hubungan partisipasi umat kristen terhadap dunia politik dan pendidikan sebagai variable (X) dengan dipengaruhi berbagai indikatornya terhadap mandat Amanat Agung sebagai variable terikat $(\mathrm{Y})$ yang dipengaruhi oleh berbagai indikatornya. Hubungan keduanya merupakan suatu keterkaitan yang tidak bisa dipisahkan. Dengan demikian maka diyakini bahwa terdapat suatu hubungan yang positif dan signifikan antara partisipsi umat kristen tehdap dunia politik dan pendidikan terhadap mandat Amnat Agung di Kabupaten Kepulauan Anambas. 


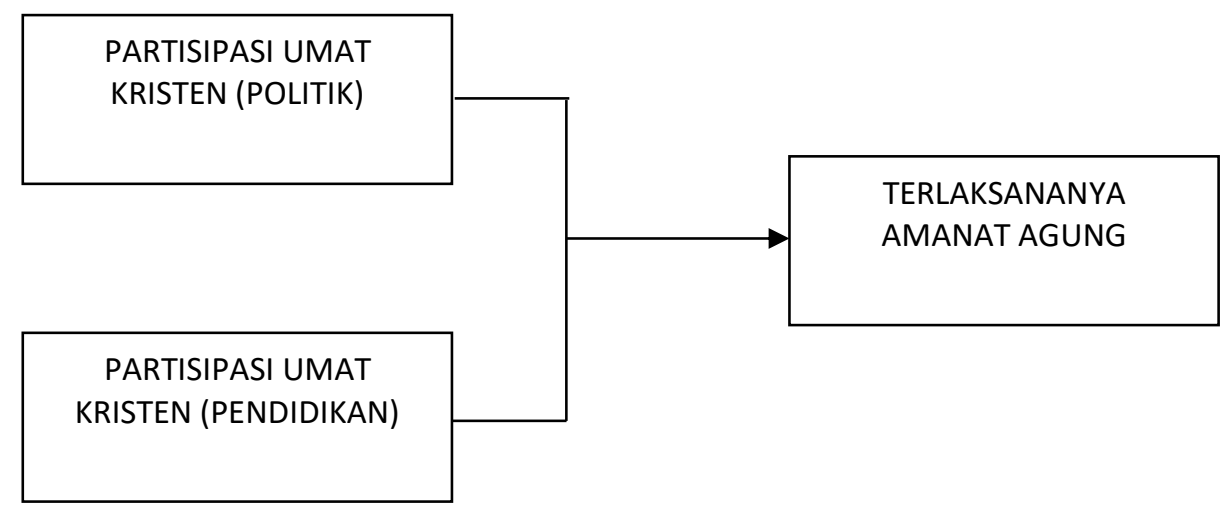

\section{Rumusan Hipotesa}

Hipotesa 1

Adapun untuk rumusan hipotesa, penulis merumuskan sebagai berikut:

Ho: Tidak terdapat hubungan yang positif dan sangan signifikan antara partisipasi umat Kristen dalam dunia politik terhadap mandat Amanat Agung wilayah Kabupaten Kepulauan Anambas.

Ha: terdapat hubungan yang positif dan signifikan antara partisipasi umat Kristen dalam dunia politik terhadap mandat Amanat Agung di wilayah Kabupaten Kepulauan Anambas.

Hipotesa 2

Ho:Tidak terdapat hubungan yang positif dan sangat signifikan antara partisipasi umat Kristen dalam dunia pendidikan terhadap mandat Amanat Agung wilayah Kabupaten Kepulauan Anambas.

Ha: Terdapat hubungan yang positif dan sangat signifikan antara partisipasi umat Kristen dalam dunia pendidikan terhadap mandat Amanat Agung wilayah Kabupaten Kepulauan Anambas.

Hipotesa 3

Ho: Tidak terdapat hubungan yang positif dan sangat signifikan antara partisipasi umat Kristen dalam dunia politik dan pendidikan secarabersama-samaterhadap mandat Amanat Agung wilayah Kabupaten Kepulauan Anambas.

Ha: terdapat hubungan yang positif dan signifikan antara partisipasi umat Kristen dalam dunia politik dan pendidikan secarabersama-samaterhadap mandat Amanat Agung di wilayah Kabupaten Kepulauan Anambas.

\section{Hasil}

Berdasarkan hasil analisis hipotesis penelitian, diperoleh informasi bahwa terdapat hubungan positif partisipasi umat Kristen dalam duniapendidikanterhadap Mandat Amanat Agung untuk memasuki dunia kerja, baik secara sendiri-sendiri maupun secara bersama- 
sama. Dengan hubungan posif yang didapat maka dapatlah disimpulkan bahwa partisipasi umat Kristen dalam dunia politik dan pendidikanberpengaruh terhadap Mandat Amanat Agung di Kepulauan Anambas.

Hasil pengujian hipopenelitian secara statistik menunjukkan bahwa semua variabel bebas terungkap mempunyai hubungan dengan variabel terikat. Hal ini menunjukkan bahwa data penelitian ini secara empiris cukup kuat untuk mendukung hipopenelitian yang diajukan dalam penelitian ini. Dengan demikian dapatlah disimpulkan bahwa:

\section{Pengaruh partisipasi umat Kristen dalam dunia politik terhadap Mandat Amanat Agung.}

Berdasarkan hasil pengujian hipopenelitian pertama yang berbunyi, "Terdapat hubungan yang signifikan antara partisipasi umat Kristen dalam dunia politik dan dengan Mandat Amanat Agung di Kepulauan Anambas". Hal tersebut ditunjukkan dengan angka koefisien $\mathrm{ry}_{1}=0,510$ pada $\mathrm{p}=0,000<0,05$. Hasil tersebut memberikan gambaran bahwa hipopenelitian yang diajukan dalam penelitian ini diterima. Dengan adanya hubungan yang signifikan, maka pujian penyembahan berkontribusi terhadap Mandat Amanat agung Di kepulauan Anambas.

Pengujian dilakukan dengan analisis regresi diperoleh tingkat pencapaian skor variabel partisipasi umat Kristen dalam dunia politik termasuk dalam kategori baik dimana tingkat pencapaian skornya adalah $85,45 \%$, hal ini sejalan dengan pendapat Sudjana (1982) yang menyatakan bahwa tingkat pencapaian dalam interval $80-89 \%$ adalah kategori baik.

Berdasarkan nilai dan koefisien korelasi yang diperoleh tersebut, maka dapat disimpulkan bahwa Partisipasi umat Kristen dalam dunia politikberpengaruh signifikan terhadap Mandat Amanat Agung. Kemudian pengaruh yang terjadi antara Partisipasi umat Kristen dalam dunia politik dengan Mandat Amanat Agung diperoleh sebesar 0,260atau $26 \%$ yang berarti semakin besar partisipasi umat Kristen dalam dunia politik, maka pelaksanaan Mandat Amanat agung juga akan semakin baik.

Hasil penelitian yang dilakukan oleh peneliti membuktikan bahwa salah satu faktor yang berpengaruh terhadap Mandat Amanat Agung adalah Partisipasi umat Kristen dalam dunia politik. Oleh karena Partisipasi umat Kristen dalam dunia politik memberikan pengaruh terhadap Mandat Amanat Agung, maka Partisipasi umat Kristen dalam dunia politik harus mendapat perhatian besar dari umat Kristen secara optimal, khususnya Para pemimpin-pemimpin Kristen di Kepulauan Anambas.

Sebagai orang Kristen yang tinggal di Indonesia kita juga memiliki tanggung jawab sebagai warga negara. Dalam hal ini kita memiliki dua kewarganegaraan yaitu warga negara kerajaan Allah ( 1 Yoh. 3:16) dan lalu kita diutus ke dunia Indonesia sehingga kita menjadi warga negara Indonesia. Oleh karena itu, kita disuruh Allah untuk berdoa demi kebaikan Indonesia (1 Tim. 2:1-2, Yes. 2:27). Sebagai orang Kristen kita harus menjadi garam dan terang di tengah - tengah masyarakat dan negara kita. Dengan sikap dan 
ketaatan kita kepada pemerintah sebagai warga negara yang baik merupakan tanggung jawab kita kepada Tuhan. Ketaatan kita kepada pemerintah adalah dalam rangka ketaatan kita kepada Allah (Kis. 5:29).

Menurut Poltak YP Sibarani dalam Bukunya: boleh kag gereja berpolitik? Melalui pokok-pokok pikiran peserta Konferensi Gereja dan Masyarakat tersebut, Gereja menunjukkan bahwa dunia politik bukanlah dunia yang terpisah dengan Gereja tetapi merupakan wilayah yang harus dilayani oleh Gereja untuk menyatakan tanda tanda Kerajaan Allah di dunia ini. Walaupun begitu, wacana politik di kalangan umat Kristen masih menjadi hal yang kontoversi bahkan sampai saat ini. Ada tiga kelompok sikap Kristen terhadap politik.

Politik tidak dapat dipisahkan dari manusia, politik dibicarakan dalam Alkitab sebagai "berita keselamatan", politik merupakan sebuah mandat bagi gereja dan politik memiliki pengaruh bagi "pekerjaan Tuhan" atau kegiatan penginjilan.

\section{Pengaruh partisipasi umat Kristen dalam dunia pendidikan Terhadap Mandat Amanat Agung.}

Berdasarkan hasil penelitian menunjukkan bahwa persentase Doa, analisis data diperoleh tingkat pencapaian skor variabel partisipasi umat Kristen dalam dunia pendidikan Terhadap Mandat Amaat Agungkuat, dimana tingkat pencapaian skornya adalah 87,17\%. hal ini sejalan dengan pendapat Sudjana (1982) yang menyatakan bahwa tingkat pencapaian dalam interval $80-89 \%$ adalah kategori baik. Berdasarkan analisa data hasil analisis hipopenelitian penelitian menunjukkan, partisipasi umat Kristen dalam dunia pendidikan berpengaruh terhadap Mandat Amanat Agung. Dari hasil analisis diperoleh derajat koefisien korelasi antara partisipasi umat Kristen dalam dunia pendidikan dengan Mandat Amanat Agung $\left(\mathrm{r}_{\mathrm{y} 2}\right)$ adalah 0,598. Berdasarkan nilai dari koefisien yang diperoleh tersebut, maka dapat disimpulkan bahwa partisipasi umat Kristen dalam dunia pendidikan berkorelasi signifikan terhadap Mandat Amaat Agung. Kemudian hubungan yang terjadi antara partisipasi umat Kristen dalam dunia pendidikan dengan Mandat Amanat Agung diperoleh sebesar 0,358 atau 35,8\%.

Hasil penelitian ini memberikan gambaran bahwa partisipasi umat Kristen dalam dunia pendidikandapat memberikan pengaruh terhadap Mandat Amanat Agung. Maka semakin meningkat bahwa partisipasi umat Kristen dalam dunia pendidikanmaka Amana Agung akan terimplementasi semakin baik karena partisipasi umat Kristen dalam dunia pendidikanyang intens akan akan membuka kesempatanbagi orang lain untuk menyaksikan ataupun melihat demonstrasi amanat agung sebagai kesaksian di tengahtengah dunia pendidikan di mana kehidupan umat Kristen yang berperilaku hidup berpadanan dengan Injil dan Amanat Agung Tuhan Yesus dapat mempengaruhi pandangan dan respon orang lain terhadap Injil. 
Oleh karena itu partisipasi umat Kristen dalam dunia pendidikan harus ditingkatkan dengan memiliki konsep, berkomitmen, konsisten dalam pemahaman dan motivasi yang murni dan sesering mungkin berpartisipasi membangun pendidikan dan dasar yang baik di instansi-instansi, sekolah-sekolah atau wadah-wadah yang berhubungan dengan pendidikan.

Partisipasi umat Kristen yang murni dalam dunia pendidikan akan membawa dampak nilai positif baik terhadap dirinya lingakungan pendidikan baik bagi para pengajar maupun peserta didik, masyarakat maupun lingkungan.

Pemaparan tersebut di atas semakin dikuatkan Menurut Poltak YP Sibarani.

Gereja terpanggil untuk menawarkan sebuah wacana yang bisa diterima oleh umum dimana kebanyakan warga dapat mengambil bagian dalamnya. Gereja harus mendukung kegiatan pengembangan dan peningkatan mutu pendidikan nasional. sejarah bangsa ini menunjukkan bahwa peranan pendidikan dalam pendirian dan pembangunan bangsa sangat mendasar. Gereja harus menjadi pihak swasta yang "terdepan" memikirkan kepentingan bangsa melalui pendidikan yang terjangkau harganya. Memang pendidikan tidak boleh tidak memiliki semangat ke Tuhanan dan moral kemanusiaan.

\section{Pengaruh partisipasi umat Kristen dalam dunia politik dan pendidikan terhadap Mandat Amanat Agung.}

Berdasarkan hasil analisis data diperoleh tingkat pencapaian skor variabel Pertumbuhan jemaat termasuk dalam kategori cukup dimana tingkat pencapaian skornya adalah 85,69\%, hal ini sejalan dengan pendapat Sudjana (1982) yang menyatakan bahwa tingkat pencapaian dalam interval $80-89 \%$ adalah kategori baik.

Hasil analisis hipopenelitian ketiga, ditemukan bahwa hipopenelitian ketiga panelitian ini: Pengaruh partisipasi umat Kristen dalam dunia politik dan pendidikan secara bersama-sama berkontribusi terhadap Mandat Amanat Agung. Dari hasil analisis uji diperoleh derajat koefisien korelasi ganda antara partisipasi umat Kristen dalam dunia politik dan pendidikan dengan Mandat Amanat Agung ( $\left.\mathrm{r}_{\mathrm{y} 1.2}\right)$ sebesar 0,633.

Berdasarkan nilai dari koefisien korelasi ganda yang diperoleh tersebut, maka dapat disimpulkan bahwa partisipasi umat Kristen dalam dunia politik dan pendidikan secara bersama-sama berkorelasi signifikan terhadap Mandat Amanat Agung. Kemudian kontribusi Mandata Amanat Agung diperoleh sebesar 85,\% yang berarti semakin baik bahwa partisipasi umat Kristen dalam dunia politik dan pendidikan secara bersama-sama, maka akan berpengaruh semakin baik terhadap implementasi Mandat Amanat Agung, sedangkan sisanya yakni kontribusi sebesar 40,1\% didapatkan dari variabel lainnnya.

The Seven Mountains dalam bukunya: “ The seven mountain: memuridkan bangsabangsa dengan strategi tujuh gunung " menyingkapkan fakta bahwa konsep pelayan sebenarnya tidak melulu 'didukung' dalam gedung gereja atau lingkup gereja saja. Ada bidang-bidang yang harus dimasuki orang-orang Kristen untuk melakukan pelayanan di 
sana, yang dikenal dengan Tujuh Gunung. Gunung-gunung ini seharusnya dimasuki oleh anak-anak Tuhan sehingga Kabar Baik diwartakan di setiap bagian di dunia ini. ${ }^{8}$ Buku ini menyingkapkan konsep pelayanan, di mana setelah kita belajar dan dibekali pelayanan dari gereja, kita harus berani "keluar" dan mulai melayani di tujuh gunung pengaruh. Maiden menulis, "Anda ditakdirkan untuk sebuah alasan dan tujuan bagi Allah! Talenta, pengurapan, kepribadian dan sejarah hidup Anda semuanya akan bersinergi ke dalam tujuan yang dinamis ketika Anda menemukan gunung Anda!” Jadi, taklukkan gunung Anda hari ini! Karena gunung-gunung ini seharusnya dimasuki oleh anak-anak Tuhan sehingga Kabar Baik dapat diwartakan di setiap bagian di dunia ini. Buku ini menyingkapkan konsep pelayanan, di mana setelah kita belajar dan dibekali pelayanan dari gereja, kita harus berani 'keluar' dan mulai melayani di tujuh gunung pengaruhi bumi.

\section{KESIMPULAN}

Berdasarkan hasil penelitian yang disajikan dalam bentuk deskriptif, analisis data, pengujian hipopenelitian dan pembahasan, maka ditarik kesimpulan sebagai berikut:

1. Partisipasi umat kristen dalam dunia politik berkontribusi signifikan terhadap mandat Amanat Agung dengan koefisien korelasi ( $\mathrm{r}$ ) sebesar.0.510 koefisien determinasi ( $\left.\mathrm{R}_{\text {square }}\right)$ 0.260. Partisipasi umat kristen dalam dunia politik berkontribusi terhadap manadat amanat Agung di Kabupaten Kepulauan Anambas adalah sebesar 26\% pada taraf signifikan $\alpha=5 \%$. Hal ini menunjukkan bahwa semakin baik pelaksanaan Partisipasi umat kristen dalam dunia poloitik secara korporat, keluarga, dan pribadi maka damapak terhadapa mandat amanat Agung semakin nyata. Partisipasi dalam dunia pendidikan berkontribusi signifikan terhadap manadat Amanat Agung dengan koefisien korelasi (r) sebesar 0.598 dan koefisien determinasi $\left(\mathrm{R}_{\text {square }}\right)$ sebesar 0.358 .

2. Kontribusi Partisipasi dalam dunia pendidikan dengan manadat Amanat agung adalah sebesar $35,8 \%$ pada taraf signifikan $\alpha=5 \%$. Hal ini menunjukkan bahwa seamkin besar Partisipasi dalam dunia pendidikan, maka damapak terhadap manadat Amanat agung semakin baik.partisipasi dalam dunia politik dan

3. Partisipasi dalam dunia pendidikan secara simultan berkontribusi signifikan terhadap mandat Amanat agung dengan koefisien korelasi ganda (r) sebesar 0.633 dan koefisien determinasi ( $\mathrm{R}_{\text {square }}$ ) sebesar 0.401.Artinya dengan semakin baiknya partisipasi umat kristen dalam dunia politik secara korporat, pribadi dan semakin besar Partisipasi umat kristen dalam dunia pendidikan maka, kehidupan gereja dalam mandat amanat Agung semakin baik.

\footnotetext{
${ }^{8}$ 2012, The Seven Mountain: Memuridkan Bangsa-Bangsa Dengan Strategi Tujuh Gunung (Jogjakarta:
} ANDI, n.d.). 


\section{Implikasi}

Hasil penelitian ini merupakan usaha untuk melihat tingkat partisipasi umat kristen dalam dunia politik dan pendidikan terhadapa manadat Amanat Agung di Kabupaten Kepulauan Anambas. Hasil penelitian mengenai variabel partisipasi umat kristen dalam dunia politik dan partisipasi umat kristen dalam dunia pendidikan baik sendiri atau simultan adalah salah satu upaya peningkatan kehidupan warga gereja terhadap mandat Amanat Agung..

Implikasi dari hasil penelitian ini bagi jemaat/umat kristen adalah jemaat semakin sering dibimbing dalam kehidupan mereka, mereka akan menemukan tujuan Allah dalam hidup mereka melalui partisipasi umat kristen dalam dunia politik dan pendidikan secara berkesinambungan.Untuk meningkatkan partisipasi umat kristen dalam dunia politik dan pendidikan ini maka Gereja secara organisasi dan para pemimpin ataupun aktivis gereja harus semakin terbuka dan berpartisipasi didalam setiap aspek kehidupan dengan melakukannya seolah-olah hanya kepada Tuhan Yesus Kristus, lebih daripada sekedar menjalankan atau mengikuti aktifitas ibadah berdasarkan liturgi gereja, dengan demikian mereka terbiasa menerapkan gaya hidup yang mereka dapatkan dari gereja di mana mereka bertumbuh sehingga jemaat semakin termotivasi untuk terlibat dalam meresponi Allah sebagai yujud dalam partisipasi umat kristen dalam dunia politik dan pendidikan sebagai implikasi bagi para hamba Tuhan adalah sebagai maksud untuk memperlengkapi pengertian dan wawasan tentang partisipasi umat kristen dalam dunia politik dan pendidikan bagi Gereja dan para hamba Tuhan yang mengharapkan pengembangan dan pungsi gereja secara konstan.

\section{KEPUSTAKAAN}

2012. The Seven Mountain: Memuridkan Bangsa-Bangsa Dengan Strategi Tujuh Gunung. Jogjakarta: ANDI, n.d.

Matondang, H.V. Percakapan Dengan Dr.T.B Simatupang. Jakarta: BPK Gunung Mulia, 1989.

Samuel T. Gunawan, M. "Melaksanakan Amanat Agung Kristus." Situs Artikel Kristen Indonesia, 2017. http://artikel.sabda.org.

Simanjuntak, Fredy. "Kecerdasan Emosi Pemimpin Sebagai Tolok Ukur Gereja Yang Sehat." Real Didache 2, no. 1 (2017): 29-53.

Singgih, E.G. Iman Dan Politik Dalam Era Reformasi ( Jakarta: PT BPK GUNUNG MULIA ) 2000 Hal 48. Jakarta: BPK Gunung Mulia, 2000.

Widjaja, Fransiskus Irwan. "Peran Gereja Terhadap Kehidupan Politik Di Wilayah Kepulauan Riau.” Real Didache 1, no. 2 (2016): 117-140. 